\title{
PENINGKATAN KEMAMPUAN MENULIS PUISI SISWA KELAS V SD INPRES BATULAPPA KABUPATEN BARRU MELALUI SISTEM PEMBELAJARAN EMOSIONAL
}

\author{
Muhammad Dirham S. \\ Universitas Muhammadiyah Makassar \\ dirham@gmail.com
}

\begin{abstract}
Abstrak
Penelitian ini bertujuan mendeskripsikan perencanaan, penggunaan, dan penilaian peningkatan kemampuan Menulis Puisi Siswa Kelas V SD Inpres Batulappa Kabupaten Barru melalui Sistem Pembelajaran Emosional. Penelitian ini merupakan jenis Penelitian Tindakan Kelas (PTK). Data penelitian adalah tindakan berupa respons tingkah laku guru dan siswa dalam interaksi pembelajaran di kelas. Sumber data penelitian ini adalah guru dan siswa kelas V SD Inpres Batulappa Kabupaten Barru dengan jumlah siswa 19 orang. Teknik pengumpulan data dengan teknik tes, pengamatan, dan wawancara. Adapun teknik analisis data dengan (1) Menelaah seluruh data yang telah terkumpul, (2) reduksi data, (3) penyajian data atau memaparkan data, dan (4) menyimpulkan data. Hasil penelitian menunjukkan bahwa perencanaan pembelajaran telah terlaksana dengan baik. Pelaksanaan pembelajaran mulai dari kegiatan awal, kegiatan inti, dan kegiatan akhir dapat meningkatkan kemampuan Menulis Puisi Siswa Kelas V SD Inpres Batulappa Kabupaten Barru. Berdasarkan data yang diperoleh bahwa persentase ketuntasan belajar siswa mengalami peningkatan pada siklus I jumlah siswa yang tuntas 14 siswa dengan persentase $73 \%$ dan pada siklus II jumlah siswa yang tuntas 19 siswa dengan persentase 94,74\% kualifikasi sangat baik 18 siswa dan 1 siswa kualifikasi baik persentase 5,26\%. Pada tahap pelaksanaan juga terjadi peningkatan. Proses pembelajaran berlangsung dengan sangat baik dengan keinginan siswa untuk mengikuti seluruh proses pembelajaran yang dilakukan guru di kelas. Pada penilaian kemampuan menulis puisi dengan sistem pembelajaran emosional, guru lebih mampu melakukan penilaian secara komprehensif yaitu penilaian hasil dan penilaian proses. Oleh karena itu, disarankan kepada guru Bahasa Indonesia agar dapat menggunakan sistem pembelajaran emosional dalam pembelajaran kemampuan menulis puisi.
\end{abstract}

Kata Kunci: Keterampilan, menulis, puisi, emosional

\begin{abstract}
This research aimed to describe planning, implementing, and assessing the improvement of the students to write poem at the fifth grade of SD Inpres Batulappa Kabupaten Barru through emotional system. This research was a classroom action research. The data of this research was the response of attitudes between the teacher and the students in the classroom interaction. The data sources were the teacher and the students of SD Inpres Batulappa Kabupaten Barru with the 19 students. The techniquies of collecting dat were (1) analyzing the data collected, (2) data reduction, (3) data presentation, and (4) data conclusion. Research findings indicated that (1) the planning of learning has been done well. The implementation of learning from the pre activity, main activity, and post activity can increase the students' ability in writing poem at the fifth grade students' of SD Inpres Batulappa Kabupaten Barru. Based on the data was gained that the score standardization of the students improved in first cycle. The number of the students was 14 with the percentage $73 \%$ and the second cycle consisted of 19 students with the percentage 94, 74\%. The students categorized very good was 18 and the students categorized good was 1 with the percentage 5, $26 \%$. The process of learning was running well in the classroom. In assessing of writing ability by using emotional learning system, the teacher used comprehensive assessment such as result assessment. Further, it was suggested to the Indonesian teacher to use emotional learning system in writing poem.
\end{abstract}

Key words: Skill, Writing, Poetry, emotional 


\section{PENDAhuluan}

Di Indonesia, para ahli pendidikan pun sudah mulai melakukan penelitian mengenai optimalisasi pemanfaatan fungsi otak dalam pembelajaran dan mendalami masalah ini. Salah seorang di antaranya adalah Taufiq Pasiak. Ia mengatakan bahwa "penggunaan riset-riset otak dalam dunia pendidikan wajib dilakukan. Bukan saja karena pendidikan mensyaratkan adanya otak (betapa sulitnya mendidik orang yang tak berotak atau otak nirnormal), tetapi juga karena pendidikan memiliki tujuan mengoptimalkan penggunaan otak" (Given, 2007: 29).

Semua yang dikemukakan di atas pada akhirnya bermuara pada satu titik persoalan, yaitu bagaimana membiasakan peserta didik menggunakan dua kemampuan berfikirnya, yaitu rasional dan emosional. Dalam hal ini, Goleman (1995: 11) mengatakan bahwa "yang satu merupakan tindakan pikiran emosional, yang lain merupakan tindakan pikiran rasional. Dalam pengertian yang sesungguhnya, kita memiliki dua pikiran, satu yang berpikir, dan satu yang merasa". Kedua pikiran tersebut harus bekerja dalam satu keselarasan yang erat dan saling melengkapi. Emosi memberi masukan dan informasi kepada proses pikiran rasional dan pikiran rasional memperbaiki serta terkadang memfeto masukan emosional tersebut. Namun, keduanya merupakan kemampuan yang semi mandiri. Artinya, keduanya memiliki sistem kerjanya sendiri-sendiri yang merupakan dua sirkuit kerja yang berbeda dalam otak namun dalam melakukan fungsinya, keduanya saling terkait.

Dalam hubungan ini, Pasiak (2007: 41) mengatakan bahwa "pendidikan lebih dari sekadar meraih standar pembelajaran tertentu, pendidikan identik dengan mengembangkan keinginan untuk belajar, memahami cara belajar, dan menerapkan praktik pengajaran berdasarkan bagaimana sesungguhnya otak berfungsi”. Given (dalam Pasiak, 2007: 42) membagi sistem pembelajaran berdasarkan fungsi-fungsi otak tersebut menjadi enam sistem, yaitu sistem pembelajaran emosional, sistem pembelajaran sosial, sistem pembelajaran kognitif, sistem pembelajaran fisik, sistem pembelajaran reflektif, dan sistem pembelajaran yang merupakan gabungan kelima sistem yang ada. Keenam sistem pembelajaran ini jika benar-benar dijalankan dengan baik akan mengoptimalkan fungsi otak.

Dari keenam sistem pembelajaran ini, sistem pembelajaran emosional merupakan sistem yang sangat penting. Given (2007:79) mengatakan bahwa "sistem pembelajaran emosional otak menentukan individualitas seseorang dan menata panggung baginya untuk berinteraksi dengan orang lain, belajar, berperilaku, dan mencerminkan keadaannya". Artinya, kecerdasan emosional seseorang akan menentukan bagaimana orang itu memposisikan dirinya dalam setiap kesempatan dan peristiwa serta pergaulan di lingkungan masyarakat yang dinamis. Golema (1995:149) menjelaskan betapa peran emosi itu sangat penting. Dikatakannya bahwa "orang yang mengalami gangguan emosional tidak bisa mengingat, memperhatikan, belajar, atau membuat keputusan secara jernih karena "stres membuat orang menjadi bodoh". Sementara itu, Dan Candace (dalam Given, 2007: 187) mengatakan bahwa "emosi menghubungkan tubuh dengan otak dan menyediakan energi untuk memacu prestasi akademis, juga kesehatan, dan keberhasilan pribadi. Dengan perkataan lain, bahwa bagaimana mungkin pebelajar bisa belajar dengan baik jika emosionalnya terganggu. Demikian pula bagaimana mungkin orang bergairah untuk berkreasi dan berpreastasi serta melakukan pilihan-pilihan terbaik untuk dirinya jika emosionalnya tidak stabil.

Dalam kaitannya dengan desain pembelajaran yang dirancang oleh para guru, sangat jarang dijumpai adanya desain pembelajaran yang berbasis sistem pembelajaran emosional. Selama ini, desain pembelajaran selalu berbasis sistem pembelajaran kognitif. Pelajaran tertentu, seperti pendidikan jasmani dan kesehatan berbasis sistem pembelajaran fisik. Khusus mata pelajaran bahasa Indonesia, sistem pembelajaran yang selama ini banyak digunakan adalah sistem pembelajaran kognitif, sedikit sistem pembelajaran sosial, dan reflektif. Sistem pembelajaran emosional tidak pernah digunakan secara serius. Akibatnya, kemampuan berbahasa para siswa sangat jauh di bawah standar yang dipersyaratkan untuk setiap tingkatan pendidikan. Keluhan para guru, terutama guru bahasa Indonesia, pada umumnya penguasaan bahasa Indonesia siswa sangat buruk. Bahkan, sepertinya mereka kehilangan etika dalam berbahasa. Belum lagi sikapnya terhadap 
bahasa Indonesia yang cenderung memburuk. Etika berbahasa pun demikian kejadiannya. Sementara itu, jika dibandingkan dengan nilai prestasi belajar mata pelajaran bahasa Indonesia pada buku rapor sangat tidak konsisten. Nilai yang tertera sangat tinggi, bahkan ada yang sampai menghampiri nilai sempurna, namun kemampuan pragmatik dan etika berbahasanya sangat kurang.

Kenyataan seperti ini memang menjadi sesuatu yang ironis dan mengindikasikan adanya ketidakwajaran. Dari pengamatan pendahuluan yang dilakukan pada beberapa sekolah dasar di Kecamatan Barru dapat disimpulkan bahwa ketidakwajaran itu terjadi sebagai "langkah spekulatif" untuk menunjukkan bahwa pembelajaran bahasa Indonesia di sekolah itu berhasil. Selain itu, indikasi yang lain adalah siswa tidak dapat menyerap dengan baik materi pelajaran bahasa Indonesia yang disajikan oleh guru pada proses pembelajaran, apa lagi mempraktikkannya. Hal ini terjadi karena orientasi pembelajaran bahasa Indonesia bukan pada pragmatiknya, melainkan pada penguasaan materi secara teoretis. Siswa "dicekoki" dengan berbagai materi teoretis dan dengan pendekatan, metode, dan teknik yang konvensional serta membosankan. Pada sekolah yang diamati dalam penelusuran pendahuluan, termasuk di SD Inpres Batulappa, ditemukan bahwa guru tidak menggunakan metode dan teknik yang inovatif serta cenderung mengabaikan sistem pembelajaran emosional.

Sejalan dengan hal di atas, salah satu materi pembelajaran yang sangat kurang produktif adalah menulis, khususnya menulis puisi. Pada umumnya, materi ini disajikan dengan memberi contoh puisi kepada siswa disertai informasi seperlunya, kemudian siswa ditugasi menulis puisi. Hasilnya sangat jauh dari harapan. Siswa kurang mampu mengembangkan ide tulisan menjadi puisi yang utuh dan berkualitas serta puisi yang dihasilkan hanya berupa urut-urutan kata yang tidak kohesif dan koheren. Akibatnya, puisi tersebut tidak berhasil menyampaikan ide tulisan. Hal lain yang sering terjadi adalah ketidakmampuan siswa untuk memilih ide tulisan. Kenyataan inilah yang semakin memperkuat keinginan penulis untuk meneliti hal ini lebih jauh di SD Inpres Batulappa Kecamatan Barru.

\section{TINJAUAN PUSTAKA}

\section{Pengertian Menulis}

Menurut Tarigan (1993: 1) menulis adalah salah satu keterampilan berbahasa yang dipergunakan untuk berkomunikasi secara tidak langsung, tidak secara tatap muka dengan orang lain. Berbeda dengan Keraf (1984: 19) menulis adalah a) membuat huruf dengan pena, b) melahirkan pikiran atau perasaan dengan tulisan, c) menggambar, melukis gambar pemandangan, dan d) membatik kain.

\section{Tentang Emosi}

a. Pengertian Emosi

Goleman (1995: 411) mengatakan bahwa emosi adalah istilah yang selama satu abad makna tepatnya masih membingungkan baik oleh para ahli psikologi maupun ahli filsafat. Namun demikian, beberapa pendapat mengenai pengertian emosi ini dapat dikutipkan berikut ini. Dalam Kamus Besar Bahasa Indonesia (KBBI) dijelaskan bahwa emosi adalah “(1) luapan perasaan yang berkembang dan surut dalam waktu singkat; (2) keadaan dan reaksi psikologis dan fisiologis (seperti kegembiraan, kesedihan, keharuan kecintaan); keberanian yang bersifat subjektif) (Sugono, dkk, 2008: 298). Berdasarkan pengertian ini, dapat dikatakan bahwa emosi adalah suasana psikologis yang memengaruhi fisik. Ia muncul dengan tiba-tiba ketika menerima ransangan dan berakhir dalam jangka yang relatif cepat.

b. Bentuk-bentuk Emosi

Mengenai bentuk-bentuk dan kategori emosi, Given mengatakan bahwa para ahli pun berbeda pandangan. Namun, perlu ditegaskan bahwa betapapun perbedaan itu, semuannya mengacu pada satu konsep yang sama. Misalnya Goleman (1995: 411) membaginya ke dalam delapan golongan, sebagai berikut:

1) Amarah: beringas, mengamuk, benci, marah besar, jengkel, kesal hati, terganggu, rasa pahit, berang, tersinggung, bermusuhan, dan yang paling hebat adalah tindakan kekerasan dan kebencian patologis.

2) Kesedihan, pedih, muram, suram, melankolis, mengasihani, diri kesepian, ditolak, putus asa, dan kalau menjadi patologis, depresi berat. 
3) Rasa takut, cemas, gugup, khawatir, was-was, perasaan takut sekali, waspada, sedih, tidak tenang, ngeri, kecut, sebagai patologi, fobia dan panik.

4) Kenikmatan, bahagia, gembira, ringan, pusing, riang, senang, terhibur, bangga, kenikmatan indrawi, takjub, rasa terpesona, rasa puas, rasa terpenuhi, kegirangan luar bisa, senang, senang sekali, dan batas ujungnya adalah mania.

5) Cinta, penerimaan, persahabatan, kepercayaan, kebaikan hati, rasa dekat, bakti, hormat, kasmaran, kasih.

6) Terkejut, terkesiap, takjub, terpana

7) Jengkel, hina, jijik, muak, mual, benci, tidak suka

8) Malu, rasa salah, malu hati, kesal hati, sesal, hina, aib, dan hati hacur lebur.

\section{Sistem Pembelajaran Emosional}

Sistem pembelajaran emosional adalah salah satu dari lima sistem pembelajaran yang diperkenalkan oleh Barbara K. Given. Ia tentunya bukan orang pertama yang mengemukakan hal ini, tetapi dialah yang berhasil menyederhanakan pembahasan tentang pemanfaatan fungsi alamiah otak dalam pembelajaran (Pasiak, 2007: 28).

Given (2007: 85) mengatakan bahwa sistem pembelajaran emosional merupakan sistem saraf kompleks yang tersebar luas. Dikatakan sistem saraf kompleks karena dalam menjalankan fungsinya, satu bagian otak harus terkombinasi dengan bagian yang lain. Pasiak (2007: 71) menganjurkan kepada guru agar mengajar dengan berbagai gaya pembelajaran yang berbeda supaya potensi setiap pebelajar dapat dibangunkan.

Dari beberapa pengertian dan teori tentang sistem pembelajaran emosional yang telah dipaparkan, dapat disimpulkan bahwa sistem pembelajaran emosional adalah sistem pembelajaran yang memungkinkan siswa untuk belajar mandiri, mencari, dan menemukan sendiri apa yang seharusnya dia pelajari, serta mengontrol emosi negatif dan mengembangkan emosi positifnya.

\section{Menulis Puisi}

\section{a. Pengertian Puisi}

Secara etimologi, istilah puisi berasal dari bahasa Yunani "Poem" yang berarti "membuat" atau "Poeisis" yang berarti "Pembuatan". Puisi diartikan "membuat" dan "pembuatan" karena lewat puisi pada dasarnya seseorang telah menciptakan suatu dunia tersendiri yang berisi pesan atau gambaran suasanasuasana tertentu, baik fisik maupun ilmiah.

b. Unsur-unsur Puisi

Unsur pembangun puisi ada dua, yaitu unsur fisik dan unsur mental. Unsur fisik adalah segala unsur yang kelihatan kalau puisi dituliskan dan yang kedengaran ketika puisi dibacakan. Unsur fisik ini meliputi baris, bait, tipografi, dan bunyi yang tersusun dalam bentuk kata-kata. Unsur mental adalah unsur yang tidak kelihatan dan kedengaran. Unsur ini ditimbulkan oleh unsur fisik. Unsur mental ini meliputi arti atau makna, tema, asosiasi-asosiasi, citra, dan emosi, Boulton (dalam Semi 1994: 96). Apabila dibuat hierarki, puisi itu terdiri atas lapisanlapisan. Lapisan pertama menimbulkan lapisan kedua, lapisan kedua menimbulkan lapisan ketiga, dan seterusnya. Lapisan partama adalah unsur fisik puisi; lapisan kedua adalah arti unsur fisik; dan lapisan ketiga adalah pelaku, latar, objek-objek yang dikemukakan yang secara bersama-sama melahirkan tema, amanat, dan interpretasi yang disebut lapisan dunia (pemikiran).

\section{Merancang Desain Pembelajaran Berbasis Sistem Pembelajaran Emosional}

Telah dikemukakan bahwa pada dasarnya sistem pembelajaran emosional adalah sistem pembelajaran yang melibatkan sistem saraf kompleks otak; sistem pembelajaran yang dirancang sedemikian rupa sehingga siswa termotivasi untuk mau belajar mandiri serta mengontrol emosi negatif dan mengembangkan emosi positifnya, terhindar dari perasaan takut dan cemas, serta rasa amarah dan kalap.

Sementara itu, dalam KBBI (Sugono, dkk., 2008: 17) dijelaskan bahwa pembelajaran berarti proses, cara, perbuatan menjadikan orang atau makhluk hidup belajar. Dalam pengertian bahwa pada kegiatan pembelajaran ada dua pihak yang terlibat, yaitu pengajar (orang yang mengajar) dan pembelajar (orang yang belajar).

Langkah-langkah meningkatkan kemampuan menulis puisi melalui sistem pembelajaran emosional: 
1) Guru mempersiapkan dan menyediakan lingkungan yang kondusif bagi siswa untuk menulis puisi.

2) Guru menciptakan iklim pembelajaran menulis puisi yang demokratis bagi siswa dengan bertanya kepada siswa tempat apa yang mereka sukai.

3) Guru mengembangkan sikap empati dan merasakan apa yang sedang dirasakan siswa serta meminta siswa menuangkan imajinasi mereka ke dalam puisi.

4) Membantu siswa menemukan kosakata dalam setiap masalah yang dihadapi siswa untuk selanjutnya dituangkan ke dalam puisi.

5) Melibatkan siswa secara optimal dalam pembelajaran menulis puisi yang sedang berlangsung.

6) Merespons setiap perilaku siswa secara positif dan menghindari respon yang negatif melalui pemilihan kosakata yang digunakan siswa dalam puisi.

\section{METODE PENELITIAN}

\section{Jenis Penelitian}

Penelitian ini termasuk penelitian deskriptif kualitatif yang didesain melalui penelitian tindakan kelas (class room action research) yang bertujuan meningkatkan kemampuan menulis puisi siswa kelas V SD Inpres Batulappa Kabupaten Barru melalui Sistem Pembelajaran Emosional. Penelitian tindakan kelas dilaksanakan dalam bentuk bersiklus yang terdiri atas empat tahap yaitu perencanaan, pelaksanaan tindakan, observasi, dan refleksi.

\section{Fokus Penelitian}

Fokus dalam penelitian ini adalah 3 faktor yang diselidiki, yaitu : faktor siswa, proses, dan hasil.

1) Faktor siswa, yaitu melihat persentase kehadiran siswa, siswa yang bertanya materi pelajaran yang belum dimengerti, kemajuan belajar siswa, serta kemampuan menulis puisi siswa.

2) Faktor proses, yaitu melihat keaktifan siswa, interaksi siswa dengan guru dan antar siswa dengan siswa lainnya dalam proses belajar mengajar.

3) Faktor hasil, yaitu melihat hasil kemampuan menulis puisi melalui system pembelajaran emosional siswa setelah tes akhir yang diberikan setiap siklus.
Sumber data proses, yaitu guru dan siswa saat pembelajaran menulis puisi berlangsung setiap siklus. Sumber data hasil diperoleh dari siswa yang berjumlah 19 orang, terdiri atas 14 laki-laki dan 5 perempuan. Penelitian ini dilaksanakan pada semester ganjil 2011/2012.

\section{Prosedur Penelitian}

Penelitian ini menggunakan rancangan penelitian tindakan kelas. Pelaksanaan penelitian tindakan kelas yerdiri dari beberapa tahap yang berlangsung dalam bentuk siklus. Tahapan prosedur pelaksanaan penelitian tindakan kelas ini menggunakan model Kemmis dan Mc Taggart. Setiap siklus terdiri atas empat tahap, yaitu (1) perencanaan, (2) pelaksanaan, (3) pengamatan, dan (4) refleksi (Rofi udin, 2002: 63-64).

a. Tahap Perencanaan

Hasil studi penelitian menunjukkan bahwa kemampuan menulis puisi siswa masih rendah, pembelajaran bersifat tradisional, pembelajaran didominasi guru sehingga siswa berlaku pasif. Berdasarkan hasil studi pendahuluan tersebut, disusunlah rencana tindakan. Penyusunan rencana tindakan dilakukan secara kolaboratif antara peneliti dengan guru Bahasa Indonesia yang lain khususnya yang mengajar di kelas kelas V SD Inpres Batulappa Kabupaten Barru. Hal itu sesuai dengan karakteristik penelitian kelas, yaitu bersifat kolaboratif atau kooperatif artinya, dalam pelaksanaan penelitian tindakan kelas selalu terjadi kerjasama antara penelitian (guru) dan pihak lain (kolaborator) demi keabsahan dan tercapainya tujuan penelitian (Depdiknas, 2006: 37).

Perencanan tindakan meliputi beberapa kegiatan yang diuraikan berikut ini.

1) Menyusun rancangan proses pembelajaran dengan menggunakan Sistem Pembelajaran Emosional (SPE). Rancangan tindakan ini disusun dalam bentuk Rencana Pelaksanaan Pembelajaran (RPP).

2) Menyimpulkan Rencana Pelaksanaan Pembelajaran yang telah disusun untuk memberikan pemahaman, keterampilan, dan penyamaan persepsi kepada guru Bahasa Indonesia dan siswa kelas V SD Inpres Batulappa Kabupaten Barru. 
3) Menetapkan deskriptor dan kriteria pencapaian pembelajaran menulis puisi.

4) Menyiapkan alat perekam data proses dan hasil pembelajaran berupa pedoman observasi, tes, dan pedoman wawancara.

b. Tahap Pelaksanaan Tindakan dan Pengamatan Tahap ini merupakan penerapan rencana tindakan yang telah disusun oleh peneliti dan guru (kolaboratif) sesuai dengan rencana pembelajaran yang telah disusun. Pada tahap ini dilaksanakan kegiatan berikut ini.

1) Guru Bahasa Indonosia kelas V SD Inpres Batulappa Kabupaten Barru melaksanakan tindakan pembelajaran berdasarkan Rencana Pelaksanaan Pembelajaran (RPP) yang telah disusun.

2) Peneliti melakukan pengamatan terhadap proses pembelajaran yang sedang berlangsung. Peneliti mengamati dan mencatat proses pembelajaran yang meliputi aktivitas siswa, interaksi guru dan siswa, antara siswa dengan siswa dengan menggunakan instrumen pengumpul data yang telah dibuat pada tahap perencanaan tindakan. Pengamatan dilakukan secara menyeluruh terhadap semua kejadian selama proses pembelajaran meningkatkan kemampuan menulis puisi melalui sistem pembelajaran emosional.

\section{c. Tahap Refleksi}

Pada tahap ini, peneliti dan kolaboratif mendiskusikan hal-hal berikut, yaitu (1) kesesuaian antara rencana dengan pelaksanaan pembelajaran, (2) kekurangan yang terjadi selama proses pembelajaran, (3) kemajuan yang dicapai siswa, dan (4) rencana tindakan pembelajaran siklus selanjutnya.

Kesesuaian antara RPP dengan pelaksanaan, kekurangan yang terjadi selama proses pembelajaran dan kemajuan yang dicapai oleh siswa dapat diketahui setelah peneliti dan kolaboratif melakukan analisis data pada setiap siklus. Dalam penelitian ini. Peneliti dan kolaboratif melakukan analisis data sebagai bahan refleksi.

\section{Teknik Pengumpulan Data dan Instrumen Penelitian}

Teknik pengumpulan data yang dilakukan dalam penelitian ini adalah teknik pengamatan (observasi), tes, dan wawancara. Untuk mengumpulkan data yang diperlukan, peneliti menggunakan instrumen utama dan instrumen penunjang. Instrumen utama dalam penelitian ini adalah peneliti. Peneliti menjadi instrumen utama dalam penelitian ini karena peneliti berperan penting dalam keseluruhan proses penelitian. Dalam pengumpulan data, instrumen penunjang yang digunakan yaitu pedoman pengamatan, tes hasil belajar, dan pedoman wawancara.

\section{Teknik Analisis Data}

Analisis data dilakukan berdasarkan teknik analisis data model mengalir yang dikembangkan oleh Miles dan Huberman (dalam Rofi'udin, 2002: 78). Proses analisis data mengikuti langkah-langkah berikut:

1) Menelaah seluruh data yang telah terkumpul.

2) Melalui reduksi.

3) Menyajikan data atau memaparkan data.

4) Menyimpulkan data.

5) Data yang dianalisis.

\section{HASIL PENELITIAN DAN PEMBAHASAN}

\section{Hasil penelitian siklus I}

Berdasarkan data yang diperoleh, maka pada hasil penelitian siklus I dipaparkan tentang perencanaan pembelajaran, pelaksanaan pembelajaran, penilaian pembelajaran, dan refleksi.

a. Perencanaan Peningkatan Kemampuan Menulis Puisi Siswa Kelas V SD Inpres Batulappa Kabupaten Barru melalui Sistem Pembelajaran Emosional siklus I.

Secara terstruktur, perencanaan pembelajaran tersebut disusun secara kolaboratif antara guru mitra dan peneliti meliputi Sembilan komponen, yaitu: (1) standar kompetensi, (2) kompetensi dasar, (3) alokasi waktu, (4) merumuskan indikator pembelajaran, (5) tujuan pembelajaran (6) mengembangkan materi pembelajaran, (7) menyusun skenario pembelajaran, (8) mengembangkan metode, media, dan sumber belajar, dan (9) menyusun alat penilaian.

b. Pelaksanaan Peningkatan Kemampuan Menulis Puisi Siswa Kelas V SD Inpres Batulappa 
Kabupaten Barru melalui Sistem Pembelajaran Emosional siklus I

\section{1) Pertemuan 1 siklus $I$.}

Kegiatan guru dalam pembelajaran, semuanya terlaksana. Hal tersebut membuktikan bahwa guru mendominasi rencana pembelajaran yang disusun sebelumnya. Namun demikian, masih terdapat satu kegiatan yang belum terwujud secara maksimal seperti yang direncanakan, yaitu menjelaskan langkah-langkah pembelajaran SPE dan tugas-tugas yang harus dilaksanakan oleh siswa. Kemudian dalam kegiatan individual masih ada satu dua orang yang masih bingung dalam mengerjakan tugas.

2) Pertemuan 2 siklus $I$

Kegiatan guru dalam pembelajaran, semuanya sudah terlaksana dengan baik. Hal tersebut karena belajar dari pertemuan 1 sebelumnya. Namun demikian, masih terdapat satu kegiatan yang belum terwujud secara maksimal seperti yang direncanakan, yaitu tugas-tugas yang harus dilaksanakan oleh siswa secara individu tidak ditemukan, sehingga hanya satu atau dua orang yang aktif menuliskan puisi secara bebas dengan emosi positif, yang lain hanya memberikan pendapat, juga dalam hal ini perhatian guru hanya terpaku pada yang naik saja, tidak secara menyeluruh kepada siswa, sehingga penunjukan tidak terbagi rata, hal lain adalah cara memberikan penjelasan secara baik masih.

c. Penilaian Peningkatan Kemampuan Menulis Puisi Siswa Kelas V SD Inpres Batulappa Kabupaten Barru melaluiSistemPembelajaran Emosional siklus I.

Proses pembelajaran dengan kualifikasi sangat baik yaitu 4 atau 21,05\% siswa, kualifikasi baik 7 atau 36,84\% siswa, kualifikasi cukup 5 atau 26,31\% siswa, siswa yang memperoleh kualifikasi kurang, 3 atau $15,78 \%$ siswa, dan tidak ada siswa memperoleh kualifikasi gagal.

Siswa yang antusias dalam kegiatan apersepsi 15 siswa atau 78,95\%, dalam menyimak tujuan 15 atau $78,95 \%$ siswa, memperhatikan arahan guru 13 atau $68,42 \%$ siswa, menulis puisi 17 atau 89,48 \% siswa, perhatian siswa dalam mengerjakan tugas individu 17 atau $89,47 \%$ siswa, keaktifan siswa 15 atau $78,94 \%$ siswa, keaktifan siswa dalam meminta bimbingan guru ada 7 atau $76,84 \%$ siswa, keaktifan siswa memberikan tanggapan 7 atau 36,84\% siswa, dan ada siswa meninggalkan kelas tanpa izin 1 orang atau $5,26 \%$, siswa yang konsentrasi dalam tugas 13 atau $68,42 \%$ siswa.

Siswa yang mengikuti proses pembelajaran dengan kualifikasi sangat baik adalah 6 orang siswa atau $31,8 \%$, kualifikasi baik 8 atau $42,10 \%$, kualifikasi cukup 3 atau 15,79\% siswa, kualifikasi kurang 2 siswa atau 10,53\%, dan tidak ada siswa yang berkualifikasi gagal.

Siswa yang antusias dalam kegiatan apersepsi 17 siswa atau $89,74 \%$, dalam menyimak tujuan 15 atau 78, $95 \%$ siswa, memperhatikan arahan guru 15 atau $78,95 \%$ siswa, menulis puisi 18 atau $94,74 \%$ siswa, perhatian siswa dalam mengerjakan tugas individu 17 atau $89,48 \%$ siswa, keaktifan siswa dalam kerja 15 atau 78,95 siswa, keaktifan siswa dalam meminta bimbingan guru ada $10 \%$ atau 52,63\% siswa, keaktifan siswa memberikan tanggapan 10 atau 52,63 $\%$ siswa, tidak ada siswa meninggalkan kelas tanpa izin, dan siswa yang tetap konsentrasi dalam tugas 15 atau $78,95 \%$ siswa.

d. Refleksi Peningkatan Kemampuan Menulis Puisi Siswa Kelas V SD Inpres Batulappa Kabupaten Barru melalui Sistem Pembelajaran Emosional Siklus I

Pelaksanaan pembelajaran pertemuan I dan pertemuan II dapat dikatakan sesuai dengan perencanaan yang disusun sebelumnya. Namun demikian, masih terdapat hal-hal yang harus diperbaiki dalam pelaksanaan pembelajaran tersebut. Pada tahap kegiatan awal pembelajaran pertemuan I tampak bahwa hanya separuh jumlah siswa yang aktif dan memperhatikan respons guru ketika apersepsi dilakukan. Begitu juga saat guru menyampaikan tujuan pembelajaran, belum semua siswa menyimak dengan baik, pada hal mengetahui tujuan pembelajaran itu sangat penting bagi siswa.

Kelemahan pada pelaksanaan pembelajaran pertemuan I dan pertemuan II secara umum adalah pemantaun guru pada kegiatan siswa hanya di depan kelas. Untuk itu, agar kegiatan terpantau dengan baik oleh guru, guru harus memantau dengan berkeliling kelas mendatangi setiap siswa, juga saat menunjuk siswa yang berbicara diusahakan jangan berulang, berilah kesempatan pada semua siswa untuk berbicara. kegiatan ini harus dimasukkan sebagai 
catatan pada perencanaan pembelajaran siklus berikutnya.

Hal lain adalah siswa mengalami kesulitan untuk mengerjakan sendiri tugas yang diberikan, sehingga mereka selalu menanyakan ke teman yang lain. Dengan demikian, guru seharusnya mengelompokkan siswa sehingga siswa dapat secara berkelompok menjawab tugas dengan mudah.

\section{Hasil Penelitian Siklus II}

a) Perencanaan Peningkatan Kemampuan Menulis Puisi Siswa Kelas V SD Inpres Batulappa Kabupaten Barru melalui Sistem Pembelajaran Emosional siklus II

Perencanaan pembelajaran pada komponen langkah-langkah pembelajaran dibagi menjadi tiga tahap, yaitu (1) perencanaan pada kegiatan awal, (2) perencanaan pada kegiatan inti, dan (3) perencanaan pada kegiatan akhir. Perencanaan pada kegiatan awal, kegiatan inti, dan kegiatan akhir akan dilakukan oleh guru dan siswa.

Berdasarkan strategi dan pendekatan tersebut, maka metode pembelajaran yang dipilih adalah: Inquiri, sugestopedia, konstruktivisik, reseptifproduktif, respons fisik total. Sedangkan teknik yang direncanakan akan digunakan adalah: pemodelan, penyajian penemuan, inquiri, dan team teaching. Pada dua bagian yang disebut terakhir inilah terdapat sedikit perbedaan dari siklus I. Teknik dan metode yang disiapkan lebih banyak.

b) Pelaksanaan Peningkatan Kemampuan Menulis Puisi Siswa Kelas V SD Inpres Batulappa Kabupaten Barru melalui Sistem Pembelajaran Emosional siklus II।

\section{1) Pertemuan 1 siklus II}

Dari 15 daftar aktivitas siswa, terdapat 13 aktivitas siswa yang terlaksana dengan baik. Hal itu menunjukkan bahwa para siswa dapat memberi respons yang positif terhadap kegiatan pembelajaran yang dilaksanakan oleh guru. Hal ini terlihat sebagian siswa masih ragu untuk bertanya kepada guru bila kesulitan memahami maksud dalam penerapan SPE setelah menulis puisi sehingga mereka lebih cenderung bertanya kepada teman daripada guru.
Kekurangan yang terjadi pada pertemuan I ini merupakan bahan perbaikan pada pertemuan II.

\section{2) Pertemuan 2 siklus II}

Dari 16 daftar kegiatan guru dalam pembelajaran, semua daftar kegiatan dapat dilaksanakan guru. Terlaksananya semua kegiatan guru itu disebabkan oleh guru sudah mampu mengontrol setiap kegiatan pembelajaran dan usaha guru yang maksimal untuk memperbaiki segala kekurangan yang terdapat pada pertemuan I. Untuk itu, dalam hal ini kegiatan guru pada siklus II pertemuan dua ini berjalan dengan baik dan lancar.

a) Penilaian Peningkatan Kemampuan Menulis Puisi Siswa Kelas V SD Inpres Batulappa Kabupaten Barru melaluiSistemPembelajaran Emosional siklus II

Siswa yang mengikuti proses pembelajaran dengan kualifikasi sangat baik yaitu 12 atau 63,19\% siswa, kualifikasi baik 5 atau 26,31 \% siswa, kualifikasi cukup 2 orang atau 10,53\%, dan sudah tidak ada yang kurang atau gagal, ini menunjukkan bahwa proses pembelajaran memperlihatkah perubahan yang sangat baik.

Siswa yang mengikuti proses pembelajaran dengan kualifikasi sangat baik 14 atau 73,68 \%, dan 4 atau $21,05 \%$ siswa yang kualifikasi baik, satu orang atau 5,26\% berkualifikasi cukup, tidak ada berkualifikasi kurang, ataupun berkualifikasi gagal.

b) Refleksi Peningkatan Kemampuan Menulis Puisi melalui Sistem Pembelajaran Emosional siklus II

Pelaksanaan pembelajaran pertemuan I dan pertemuan II pada siklus II ini dapat dikatakan sesuai dengan perencanaan yang disusun sebelumnya.

Pujian dan motivasi yang diberikan guru sebelum apersepsi pada pertemuan II siklus I, kembali dilakukan guru pada pertemuan I dan pertemuan II siklus II. Hal ini memberi dampak yang sangat positif terhadap proses pembelajaran, yaitu pada kegiatan apersepsi dan penyampaian tujuan pembelajaran semua siswa sangat antusias dan merespons dengan baik.

Selanjutnya, selama kegiatan diskusi terlaksana pada pertemuan I dan II guru hanya memonitor, siswa diberi kebebasan untuk terlibat dalam 
pembelajaran terutama pada saat berdiskusi. Kekurangan yang terjadi pada siklus I berusaha diperbaiki pada siklus II sehingga hasilnya pun baik. Selanjutnya, penilaian proses yang dilakukan guru menunjukkan bahwa keterlibatan siswa dalam proses pembelajaran pada siklus II meningkat sangat siginifikan dibandingkan siklus I, sementara itu, penilaian hasil juga menunjukkan bahwa kemampuan siswa dalam menulis puisi juga menunjukkan adanya peningkatan yang signifikan dibandingkan dengan hasil tes siklus I.

Berdasarkan hasil refleksi tersebut, peneliti dan kolabotator menyimpulkan bahwa pelaksanaan pembelajaran tidak perlu dilanjutkan pada siklus berikutnya.

\section{Pembahasan Hasil Penelitian}

Perencanaanpeningkatan kemampuan menulis puisi melalui sistem pembelajaran emosional yang disusun dengan merumuskan setiap komponennya secara matang akan sangat memengaruhi pelaksanaan dan keberhasilan pembelajaran. Pelaksanaan peningkatan kemampuan menulis puisi pada setiap siklus melalui sistem pembelajaran emosional (SPE) dibagi dalam tiga tahap kegiatan, yaitu kegiatan awal, kegiatan inti, dan kegiatan penutup. Hasil penelitian menunjukkan bahwa pada tahap kegiatan awal telah terjadi komunikasi atau interaksi yang baik antara guru dan siswa.

Berdasarkan hasil analisis data penilaian proses maupun penilaian hasil ditemukan bahwa kemampuan siswa dalam menulis puisi melalui sistem pembelajaran emosional mengalami peningkatan yangsignifikan. Berdasarkan data yang diperoleh bahwa persentase ketuntasan belajar siswa mengalami peningkatan pada siklus I jumlah siswa yang tuntas 14 siswa dengan persentase $73 \%$ dan pada siklus II jumlah siswa yang tuntas 19 siswa dengan persentase $94,74 \%$ yang sangat baik 18 siswa dan 1 siswa dengan persentase 5,26\%.

Peningkatan ini memberikan indikasi postif, bahwa metode yang dipakai dalam penelitian ini telah berhasil. Hal yang sama dikemukakan Sukidin dkk. (2008:139) bahwa evaluasi yang positif dan negatif dapat bermanfaat untuk pengembangan pembelajaran.

\section{KESIMPULAN DAN SARAN}

\section{Kesimpulan}

Penyajian data pembahasan hasil penelitian tentang pembelajaran menulis puisi siswa kelas V SD Inpres Batulappa Kabupaten Barrumelalui Sistem Pembelajaran Emosional disimpulkan sebagai berikut:

a. Perencanaan pembelajaran sudah sesuai dengan sistem pembelajaran emosional. Melalui Sistem

Pembelajaran Emosional dalam perencanaan kemampuan menulis puisi disusun dan diwujudkan dalam bentuk rencana pembelajaran. Rencana pembelajaran disusun secara kolaboratif antara peneliti dan guru kelas V.

b. Pelaksanaan pembelajaran kemampuan menulispuisimelalui Sistem Pembelajaran Emosional sudah dilakukan dengan langkahlangkah berikut: eksplorasi dimana guru membantu siswa menulis puisi bebas dengan pilihan kata yang tepat, elaborasi dimana guru meminta siswa menentukan gagasan pokok berdasarkan pengalaman melalui kegiatan ceramah dan latihan, dan siswa menulis puisi berdasarkan gagasan pokok dengan menggunakan pilihan kata yang tepat melalui kegiatan latihan dan penugasan, konfirmasi, dimana guru bertanya jawab tentang hal-hal yang belum diketahui siswa serta guru bersama siswa bertanya jawab meluruskan kesalahan pemahaman, memberikan penguatan dan penyimpulan.

c. Pada penilaian pembelajaran kemampuan menulis puisi melalui sistem pembelajaran emosional, guru lebih mampu melakukan penilaian secara komprehensif. Guru tidak saja melakukan penilaian hasil, tetapi juga melakukan penilaian proses mulai tahap pembelajaran awal, tahap pembelajaran inti, dan tahap pembelajaran akhir. Penilaian proses direkam melalui panduan analisis kegiatan siswa dan guru dalam pembelajaran, sedangkan penilaian hasil dilakukan dengan menganalisis hasil tugas siswa dari puisi yang ditulisnya. Hasil belajar siswa mengalami peningkatan yang signifikan yaitu rata-rata 76,58 pada siklus I meningkat menjadi 91,89 pada siklus II; nilai terendah 52 pada siklusI meningkat menjadi 78 pada siklus II; dan nilai tertinggi 92 pada sikulus I meningkat menjadi 95 pada siklus II. 


\section{Saran}

Beberapa saran yang dapat dikemukakan berkaitan dengan hasil penelitian peningkatan kemampuan menulis puisi siswa kelas V SD Inpres Batulappa Kabupaten Barru melalui Sistem Pembelajaran Emosional adalah:

a. Guru pembimbing hendaknya melakukan perencanaan yang matang dengan menelaah capaian hasil belajar, menyusun rencana pelaksanaan pembelajaran, menyusun instrumen penelitian dalam teknik tes dan nontes, membuat lembar observasi, membuat lembar wawancara, berkolaborasi dengan guru kelas, serta mendesain alat evaluasi yang tepat dalam pembelajaran kemampuan menulis puisi dengan sistem pembelajaran emosional.

b. Guru pembimbing hendaknya lebih intensif dalam melaksanakan kegiatan meningkatkan kemampuan menulis puisi melalui sistem pembelajaran emosional dalam rangka memperkaya minat dan motivasi siswa terhadap pembelajaran di kelas.

c. Penilaian peningkatan kemampuan menulis puisi dengan sistem pembelajaran emosional siswa akan berhasil jika dilakukan dalam dua siklus dengan berpijak pada penilaian kategori dan ketuntasan belajar.

\section{DAFTAR PUSTAKA}

Aftaruddin. 1983. Pengantar Apresiasi Puisi. Bandung: Angkasa.

Akhadiat, Sabarti. dkk. 1996. Pembinaan Kemampuan Menulis Bahasa Indonesia. Jakarta:IKAPI.

Ambo Enre, Facruddin. 1994. Dasar-dasar Keterampilan Menulis. Ujung Pandang: Badan Penerbit IKIP.

Aminuddin. 1987. Pengantar Apresiasi Karya Sastra. Bandung: Sinar Baru Algensindo.

Arikunto. Suharsimi.1 993. Prosedur Penelitian, Suatu Pendekatan Praktik. Jakarta: Rineka Cipta.

Arsyad, dkk. 1999. Pengajaran Apresiasi Sastra. Jakarta Depdikbud.

Azhar, Arsyad. 2002. Media Pengajaran. Jakarta: Raja Grafindo.
Cleary, Linda Miller and Michael Linn D. 1993. Linguistics for Teachers. New York: McGraw-Hill, Inc.

Depdiknas. 2006a. Standar Kompetensi Lulusan untuk Satuan Pendidikan Dasar dan Menengah. Jakarta: Depdiknas.

Deporter, Bobby dan Mike Hernachi. 2004. Quantum Learning. Bandung. PT Mizan Pustaka.

Dryden, Gordon dan Jeanette Vos. 2001. Revolusi Cara Belajar, Keajaiban Pikiran SekolahMasa Depan. Bandung. Penerbit Kaifa.

Effendi, S., 1996. Bimbingan Apresiasi Puisi. Ende: Nusa Indah.

Ellis, Arthur., dkk. 1989. Elementary Language Arts Instruction. New Jersey: Englewood Cliffs.

Firman. 2003. Keterampilan Murid Kelas II SLTPN 1 Sajoanging Kabupaten Wajo Menulis Pengalaman Pribadi dalam Bentuk Puisi. Skripsi. Makasar: FBS UNM.

Given, Barbara K. 2007. Pengajaran pada Sistem Alami Otak Belajar (Terjemahan). Alexandria: Asosiasi Pengawasan dan Pengembangan Kurikulum.

Goleman, Daniel. 1995. Emotional Intelligence: Why it Can Matter More than IQ. New York: Bantam Books.

Harras， dkk. 1997. Membaca I. Jakarta: Departemen Pendidikan dan Kebudayaan Bagian Proyek Penataran Guru SLTP Setara D-III.

Hartoko, A., 1989. Pengantar Ilmu Sastra. Surabaya: Usaha Nasional.

Hernowo. 2006. Menjadi Guru, yang mau dan Mampu Mengajar secara Menyenangkan. Bandung. Mizan Learning Center. http://www.ditnagadikti.org/ditnaga/files/PIP/PKP-4c.pdf

Iskandar Wassid dan Sunendar. 2008. Strategi Pembelajaran Bahasa.Yogyakarta: PT. Remaja Rosda Karya.

Keraf, Gorys. 1984. Komposisi. Endeh: Nusa Indah.

Marahimin, Ismail. 1999. Menulis secara Populer. Jakarta: Pustaka Jaya.

Mehrabian, Lucas C. 2007. Pembelajaran Emosional Kuat berdasarkan

Belajar Cerdas. Internasional Journal of Intelligent Technology (IJIT), Vol. Jurnal Teknologi

Cerdas (IJIT), Vol. ACKNOWLEDGMENT 1, No. PENGHARGAAN 1, No 1, (2005), pp. 34-40. 1. 
Mulyasa, E.,dkk. 1998. Sanggar Sastra. Jakarta: Departemen Pendidikan dan Kebudayaan Bagian Proyek Penataran Guru SLTP Setara D-III.

Nurgiyantoro, Burhan. 2008. Penilaian Pengajaran Bahasa dan Sastra. Yogyakarta : BPEE.

Pasiak, Taufik. 2007. Kecerdasan Majemuk. Bandung: Mizan Learning Center.

Pradopo, Rahmat Djoko. 1999. Pengkajian Puisi. Yogyakarta: Gadjah Mada University Press.

Rofi'udin, A. 2002. Rancangan Penelitian Tindakan. Lokakarya Tingkat Lanjut Penelitian Kualitatif Angkatan V Tahun 1996/1997. Malang: IKIP Malang.

Rakhmat, Jalaluddin. 2007a. SQ for kid, Mengembangkan Kecerdasan Spritual Anak Sejak Dini. Bandung :

Mizan Pustaka. 2007b. Belajar Cerdas, Belajar Berbasiskan Otak. Bandung : Mizan Learning Center.

Sardiman, Arief. 2007. Media Pendidikan: Pengertian, Pengembangan, dan Pemanfaatannya. Jakarta: Raja Grafindo Persada.

Semi, M. Atar. 1990a. Menulis Efektif. Padang: Angkasa Raya. Angkasa.

Slameto. 2007. Belajar dan Faktor-faktor yang Mempengaruhinya. Jakarta. Penerbit Rineka Cipta.

Sugono, Dendi (Ed.). 2008. Kamus Besar Bahasa Indonesia (Edisi Keempat). Pusat Bahasa DEPDIKNAS :Jakarta.

Sukidin dkk. 2008. Manajemen Penelitian Tindakan Kelas. Jakarta: Insan Cendikia.

Suparno dan Yunus. 2003. Pembelajaran Bahasa Indonesia dengan Pendekatan Kontekstual. Makalah Disajikan dalam Simposium Guru di Wisma Jaya Raya Bogor, 2 - 6 November 2001.

Syafi'ie, Imam. 1998. Retorika dalam Menulis. Jakarta: Depdikbud.

Syah, Muhibbin. 2008. Psikologi Pendidikan dengan Pendekatan Baru. Bandung: Rosda Karya.

Tarigan, Djago. 1992. Materi Pokok Pendidikan Bahasa Indonesia 1. Jakarta:
Depdikbud Proyek Peningkatan Mutu Guru SD Setara D-II dan Pendidikan Kependudukan.

Tarigan, Henry Guntur. 1990. Prinsip-prinsip Dasar Sastra. Bandung: Angkasa.

.1993. Strategi Pengajaran dan Pembelajaran Bahasa. Bandung: Angkasa. 2008. Menulis sebagai Suatu Keterampilan Berbahasa. Bandung : Penerbit Angkasa Bandung.

Tompkins, Gail E. 1990. Teaching Writing Balancing Process and Product. NewYork: Macmillan Publishing Company.

Waluyo, Herman J. 1995. Teori dan Apresiasi Puisi. Jakarta: Erlangga.

Zohar, Danah dan Ian Marshall. 2003. Kecerdasan Emosional, Mengintegrasikan IQ, EQ, SQ dengan Pendekatan Holistik. Bandung: Mizan.

Zuchdi, Darmiyati. 1997. Pembelajaran Menulis dengan Pendekatan Proses. Karya Ilmiah. Fakultas Pendidikan Bahasa dan Seni IKIP Yogyakarta Tanggal 15 November 1996 (tidak dipublikasikan). Yogyakarta: IKIP.

Zulfahnur, dkk. 1997. Apresiasi Puisi. Jakarta: Departeman Pendidikan dan Kebudayaan. 